\title{
LACUSTRINE PALEOCHEMICAL INTERPRETATIONS BASED ON EASTERN AND SOUTHERN AFRICAN OSTRACODES
}

\author{
ANDREW S. COHEN ${ }^{1}$, RICHARD DUSSINGER ${ }^{2}$ and JOHNATHAN RICHARDSON ${ }^{3}$ \\ ${ }^{1}$ Department of Geology, The Colorado College, Colorado Springs, CO 80903 (U.S.A.) \\ ${ }^{2}$ R.D. 8 Box 304, Gettysburg, PA 17325 (U.S.A.) \\ ${ }^{3}$ Department of Biology, Franklin and Marshall College, Lancaster, PA 17604 (U.S.A.)
}

(Received November 23, 1982; revised and accepted April 7, 1983)

\section{ABSTRACT}

Cohen, A. S., Dussinger, R. and Richardson, J., 1983. Lacustrine paleochemical interpretations based on Eastern and Southern African ostracodes. Palaeogeogr., Palaeoclimatol., Palaeoecol., 43: 129-151.

Ostracode assemblages in modern African lakes reflect water chemistry variations and so are potentially useful as paleochemical indicators. The water chemistry ranges of 33 modern ostracode taxa have been evaluated for five parameters: total conductivity $\left(K_{20}\right)$, $\mathrm{Na}^{+}, \mathrm{Ca}^{2+}, \mathrm{Cl}^{-}$and alkalinity $\left(\mathrm{CO}_{3}^{2-}+\mathrm{HCO}_{3}^{-}\right)$. Strong correlations exist for distribution patterns of ostracodes across all of these parameters except $\mathrm{Ca}^{2+}$. Four, somewhat arbitrary, Ostracode Range Assemblages can be defined, based upon increasing alkalinity and salinity, and named for characteristic taxa. These are:

Range I, the Sternocypris assemblage $\left(K_{20}<500 \mu \mathrm{mho}\right)$

Range II, the Mecynocypria assemblage $\left(K_{20}=500-1500 \mu \mathrm{mho}\right)$

Range III, the Gomphocythere assemblage $\left(K_{20}=1500-4000 \mu \mathrm{mho}\right)$

Range IV, the Limnocy there assemblage $\left(K_{20}>4000 \mu \mathrm{mho}\right)$

An application of the ostracode typology to the fossil record, using a core from Lake Nakuru (Kenya) as an example, suggests a fluctuating alkaline lake prior to about 10,000 yr. B.P., followed by fresh-water conditions until about 8000 yr. B.P. and finally a return to higher alkalinity throughout the remainder of the Holocene. Since the core has also been studied for paleochemical interpretation based upon diatoms, an independent verification of the technique is possible. The two interpretations agree through $80 \%$ of the core, suggesting a good reliability for the method.

\section{INTRODUCTION}

There has been a considerable growth of interest in recent years among paleolimnologists in developing methodologies for the determination of lacustrine paleochemistries. These methodologies can be divided into two classes:

(1) Geochemical-typological approaches, where specific authigenic mineral assemblages are considered indicative of stability fields within a given range of ionic concentrations. This technique has most successfully been applied to 
rocks interpreted to have formed from highly concentrated brines (Cerling, 1977). Its utility is considerably reduced in more "normal" lacustrine environments, that is to say, in situations where metazoans are likely to be common and diverse.

(2) Fossil-typological approaches, where a series of fossil assemblages is used to indicate a particular overlapping range of ecological tolerances to a given ionic parameter. This class of techniques is of greater interest to the lacustrine or estuarine paleobiologist, who is trying to determine the habitat requirements and niche breadth of fossil organisms. To date, most studies of this type have centered around diatom floras.

In this paper, we will apply a technique falling in the second of these classes, lacustrine ostracode typology, to the highly variable inland waters of Eastern and Southern Africa. After discussing the modern distribution of ostracode genera and species in African lakes, as they relate to water chemistry, we will illustrate how the technique may be applied to the fossil record of Eastern African paleolakes, in an effort to unravel their paleochemical histories. Whereas the present study is directed towards African paleolimnology, it should apply (as a methodology, rather than in its specific details) to any region with lacustrine deposits, where modern and fossil ostracode assemblages are analogous.

The African inland water system, as a whole, is perhaps one of the better localities in which to conduct such a study. Temperature-induced assemblage variations are minimized in the lower-elevation (under $2000 \mathrm{~m}$ ) equatorial to subequatorial regions of Africa. Water chemistries, on the other hand, do vary enormously in this region, and the proximity of these lakes and ponds to ancient ostracode-bearing lacustrine deposits makes the region ideally situated for this type of investigation. The reader is directed to Delorme (1971a, b) and Delorme et al. (1977) for other examples of ostracode typology, as applied to Canadian inland waters, and for a more general review of the paleoecological significance of fresh-water ostracode fossils. More recently, Carbonel and Peypouquet (1979) and Peypouquet and Carbonel (1980) have published some ostracode-based paleochemical interpretations for the Pliocene-Pleistocene, Omo Basin of southern Ethiopia.

An index map (Fig.1) of Eastern Africa identifies the lakes discussed in this paper.

\section{METHODS}

Water chemistry and ostracode distribution data were collected both in field research, during the summers of 1978 and 1979, and from previously published data. A complete list of ostracode distribution papers used in this study can be obtained from the senior author on request. Only taxa with widespread modern distributions were considered for inclusion in this study. A taxon was only included if it had been recorded from three or more localities with appropriate water chemistry data. The taxa under consideration 


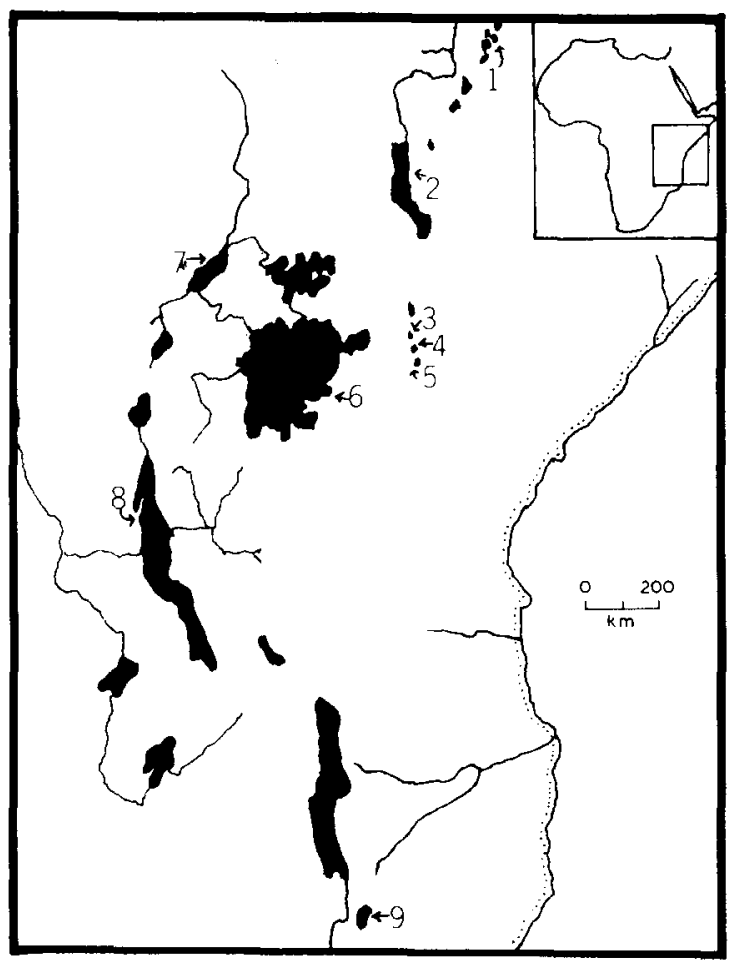

Fig.1. Location map for lakes discussed in the text: $1=$ Lake Abiata; $2=$ Lake Turkana; 3 = Lake Nakuru; 4 = Lake Elmentaita; 5 = Lake Naivasha; 6 = Lake Victoria; 7 = Lake Albert; 8 = Lake Tanganyika; 9 = Lake Chilwa.

were further reduced to include only those with known or suspected fossil records from the African Neogene.

Ideally, the taxonomic level most appropriate for this type of study is the species. Any species will have a tolerance range for any given parameter equivalent to or narrower than its encompassing higher taxon (subgenus or genus in this case). There is, however, considerable difficulty in identifying fresh-water ostracode fossils to the specific level, as most neontological taxonomic schemes for these organisms rely more heavily on soft part, nonpreservable morphology, than on carapace, preservable morphology. Therefore, only highly distinctive forms are discussed in this study at the species level. This reduces the precision of the technique considerably, but improves the accuracy of the results. An inspection of the data in Figs.2-6 (in particular for the genus Gomphocythere), shows that even highly eurytopic genera may include moderately stenotopic species, which, taken as a group, define the total, wide range of the genus. Indeed, within a particular adaptive complex, represented here by a given genus, some ostracodes are known to show considerable environmental plasticity (Delorme, 1969) as individual species. Thus, the "ranges" shown for genera here should not be construed to be 
equivalent to the range for a fossil species within that genus, but rather to encompass that individual species' probably more limited range.

\section{Water chemistry data}

The sources for water chemistry data are Wayland (1925), Worthington (1929, 1930, 1932), Omer-Cooper (1930), Phillips (1930), Beadle (1932), Damas $(1937,1954,1964)$, Ricardo (1939), Loffredo and Maldura (1941), Ricardo-Bertram et al. (1942), Fish (1952, 1953, 1954), Van Meel (1953, 1954), Dubois (1955), Talling (1957, 1963), Verbeke (1957), Van der Ben (1959), De Kimpe (1960), Harding (1963), Livingstone (1963), Talling and Talling (1965), Kilham (1971), Visser (1974), and Livingstone and Melack (1979).

In most, but not all cases, the water analyses were made at the same time as the ostracode collections. Such data were used preferentially, but were insufficient to be used exclusively in some of the large open lakes. Here, however, variations in water chemistry are small, relative to the tolerance ranges of their local ostracode faunas. This is demonstrated by comparing total chemical ranges for a given species with the variability of the same chemical parameter at the lake in question.

Five chemical parameters are considered in the present study: $\mathrm{Na}^{+}, \mathrm{Ca}^{2+}$, $\mathrm{Cl}^{-}, \mathrm{CO}_{3}^{2-}+\mathrm{HCO}_{3}^{-}$alkalinity, and total conductivity $\left(K_{20}\right) \cdot \mathrm{Na}^{+}, \mathrm{Ca}^{2+}$, and $\mathrm{Cl}^{-}$are expressed in $\mathrm{mg} / \mathrm{l}$ concentration, while alkalinity is expressed in meq/l by convention. Conductivity is expressed in $\mu \mathrm{mho} / \mathrm{cm}$ at $20^{\circ} \mathrm{C}$, and is approximately proportional to total ionic salinity in the range of salinities considered in this paper [the conversion rate being $K_{20} \simeq$ salinity (p.p.t.) $X$ $10^{3}$ ]. Conductivity data are used because they are more readily available than total salinity data.

The choice of parameters is partially dependent on data availability and partially on a consideration of the importance of particular ions for crustacean biology (Beadle, 1943). Beadle $(1974$, ch. 5) has discussed the importance of mineral composition to the ecology of African inland waters at length, so only a few points will be considered here. Most Eastern African waters are enriched in $\mathrm{Na}^{+}, \mathrm{CO}_{3}^{2-}+\mathrm{HCO}_{3}^{-}$, and $\mathrm{Cl}^{-}$, probably due to weathering of their alkaline volcanic-bearing watersheds and to arid climate fractionation processes in their feeder streams (Eugster, 1980).

Alkalinity, at higher values, regulates the solubility of $\mathrm{Ca}^{2+}$. Above approximately $80 \mathrm{meq} / \mathrm{l}$ total alkalinity, $\mathrm{Ca}^{2+}$ is available in solution only in extremely small amounts (usually less than $1 \mathrm{mg} / \mathrm{l}$ ). While no experimental evidence exists to determine the minimal concentration of $\mathrm{Ca}^{2+}$ necessary for ostracode skeletal formation, distribution data collected in this study suggest that it is approximately $1 \mathrm{mg} / \mathrm{l}$. In waters with less calcium, the crustacean fauna is composed exclusively of forms with less calcified, more chitinous exoskeletons. Beadle (1974) has noted that in the extremely calcium-poor waters of the Amazon River, conchiolin is substituted for calcite in some bivalves, 
but this type of phenomenon has yet to be observed among ostracodes (or any highly calcified crustacean to our knowledge) in Africa or elsewhere.

Additional data for major ions (particularly $\mathrm{Mg}^{2+}, \mathrm{K}^{+}$, and $\mathrm{SO}_{4}^{2-}$ ) would be extremely valuable for this type of study, but are, unfortunately, unavailable for many of the lakes and rivers considered in this study. The same may be said of major nutrients (total P, N) and trace elements. For example, La Barbera and Kilham (1974) have suggested that $\mathrm{F}^{-}$concentrations may be very significant in structuring the distribution of cladocerans and copepods in African lakes. Undoubtedly, the parameters considered in this study are not the only chemical ones of importance in the distribution of ostracode species, but the consistency of the results presented here indicates that they are very important determinants of these distributions.

It should be emphasized that the data presented here are not the result of experimental manipulation but rather are empirical distributions of natural ostracode occurrences. Though it would be of great interest to have such experimental data in order to assign absolute or lethal limits on tolerance range for these species, we are uncertain about the significance of such results for natural distributions. Many of the ions vary in concert in natural waters and their effects may be synergistic and/or inseparable by conventional experimental design. Furthermore, we are primarily concerned with the types of waters which these species inhabit, rather than the ones which they might theoretically inhabit in the absence of competition and predation. Therefore, the limits presented here are unlikely to be lethal limits for the individual. For the paleoecologist, it will ultimately be more interesting to say that the fauna of a given lacustrine deposit is similar to that of a given modern lake (which can then be used as a basis for further models of the paleolake) than to assign a set of paleochemical values to a given assemblage divorced from any observable, modern lake model. Assemblage ranges can easily be constructed from these data which have no modern analogue, and in fact lie outside of the theoretically possible range of water chemistries. For instance, a high-Ca ${ }^{2+}$ high-alkalinity water chemistry could be construed from a Gomphocythere-Limnocythere assemblage (a common fossil assemblage) given their overlapping ranges (see Figs. 4 and 5), but in fact such chemical conditions are unlikely to occur in natural waters. Thus, the interpretation of assemblages must be judiciously tempered with knowledge of the types of waters which are likely to occur and those which are not (see for example Hardie and Eugster, 1970; and Eugster and Jones, 1979). Most ostracode assemblages suggest a wide range of possible water chemistries. Their probable ranges are usually much more limited. We will return to this point in the discussion of our results, with some specific examples.

\section{RESULTS}

Figs. 2 through 6 illustrate the known chemical ranges (for the parameters previously mentioned) of 33 common ostracode species and genera. The 

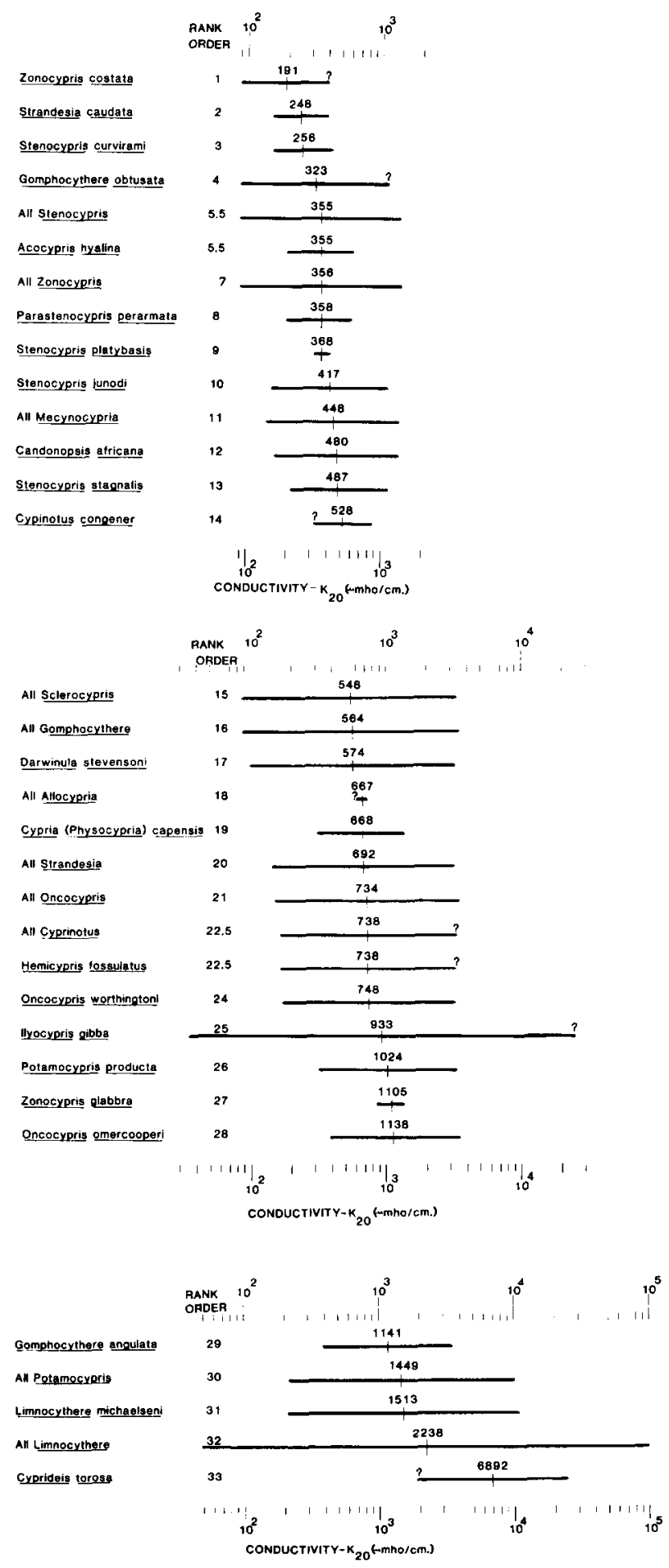

Fig.2. Total conductivity $\left(K_{20}\right)$ ranges (expressed in $\mu \mathrm{mho} / \mathrm{cm}$ ) for selected African ostracode taxa, based on natural distributions. Rank order values are based on increasing logarithmic means of minimum and maximum concentration occurrences. 


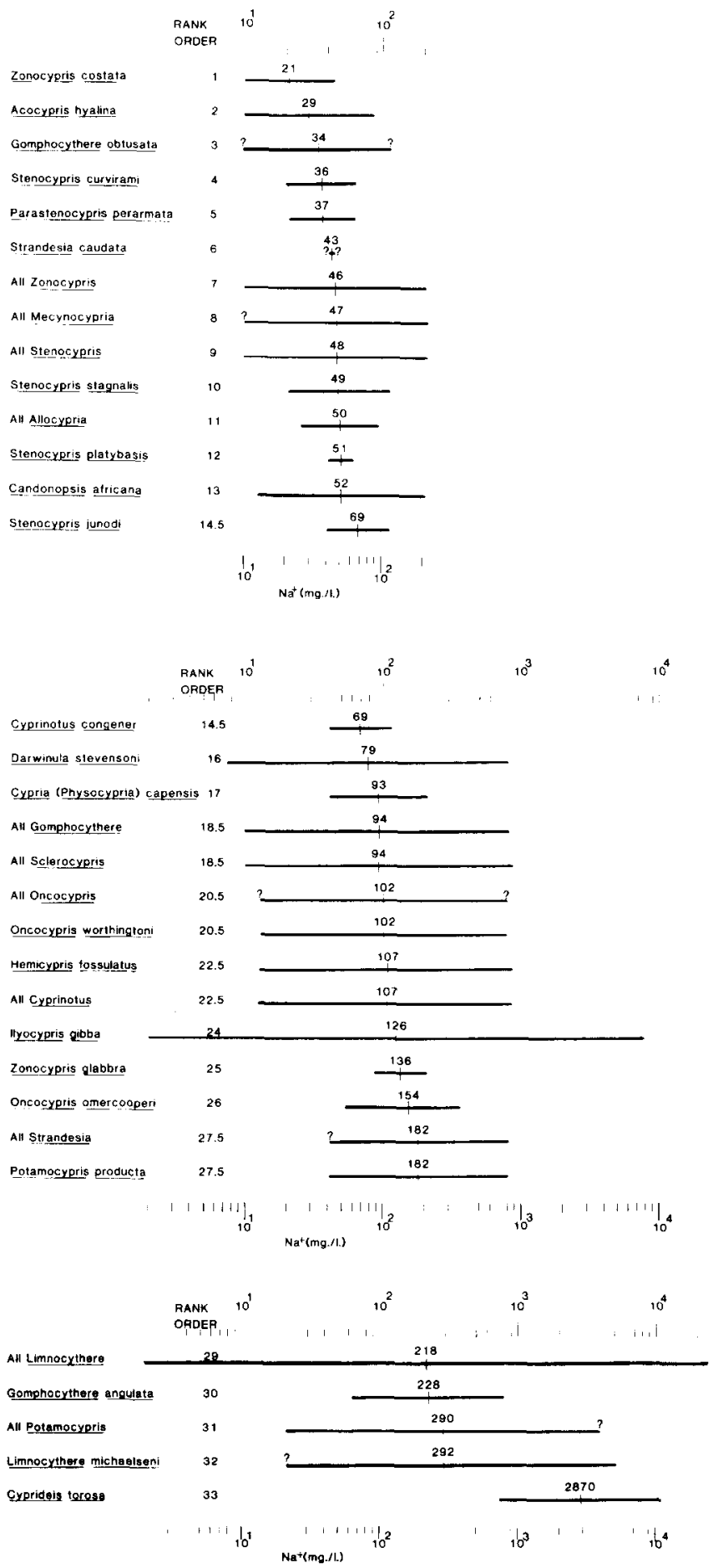

Fig. 3. $\mathrm{Na}^{+}$concentration ranges (expressed in $\mathrm{mg} / \mathrm{l}$ ) for selected African ostracode taxa, based on natural distributions. Rank order values are based on increasing logarithmic means of minimum and maximum concentration occurrences. 


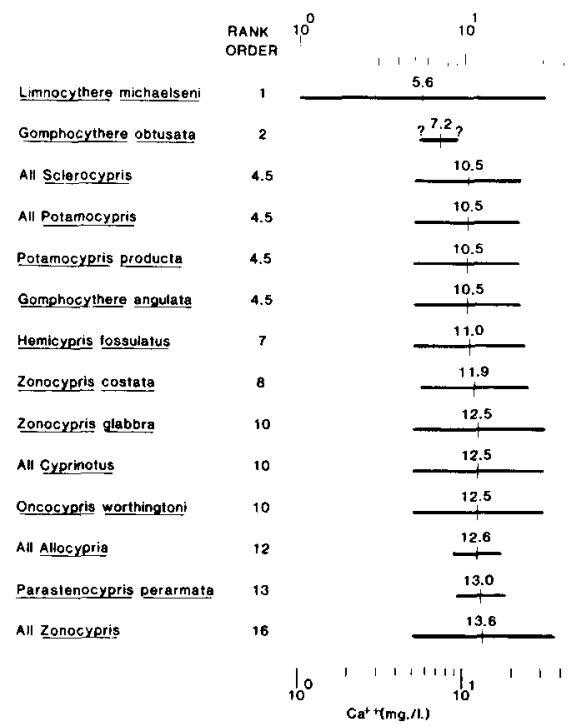

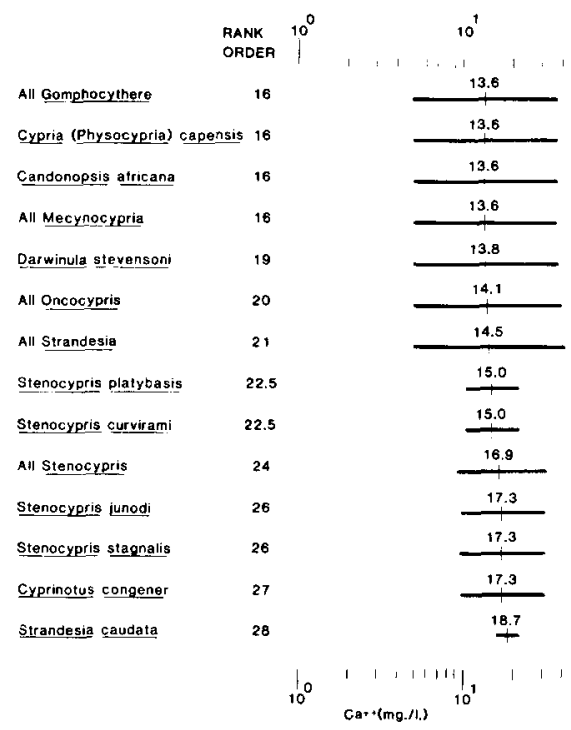

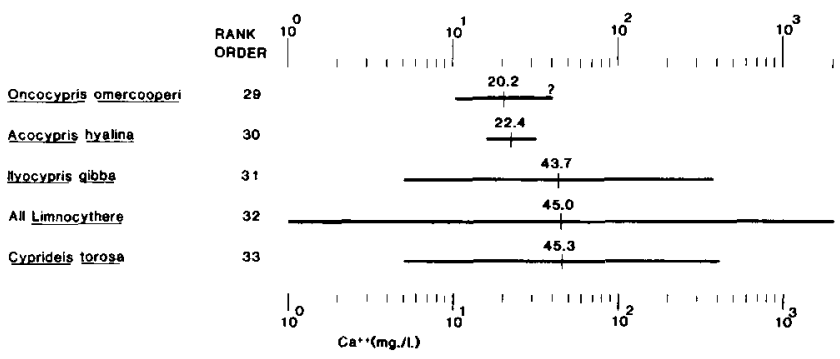

Fig.4. $\mathrm{Ca}^{2+}$ concentration ranges (expressed in $\mathrm{mg} / \mathrm{l}$ ) for selected African ostracode taxa, based on natural distributions. Rank order values are based on increasing logarithmic means of minimum and maximum concentration values. 


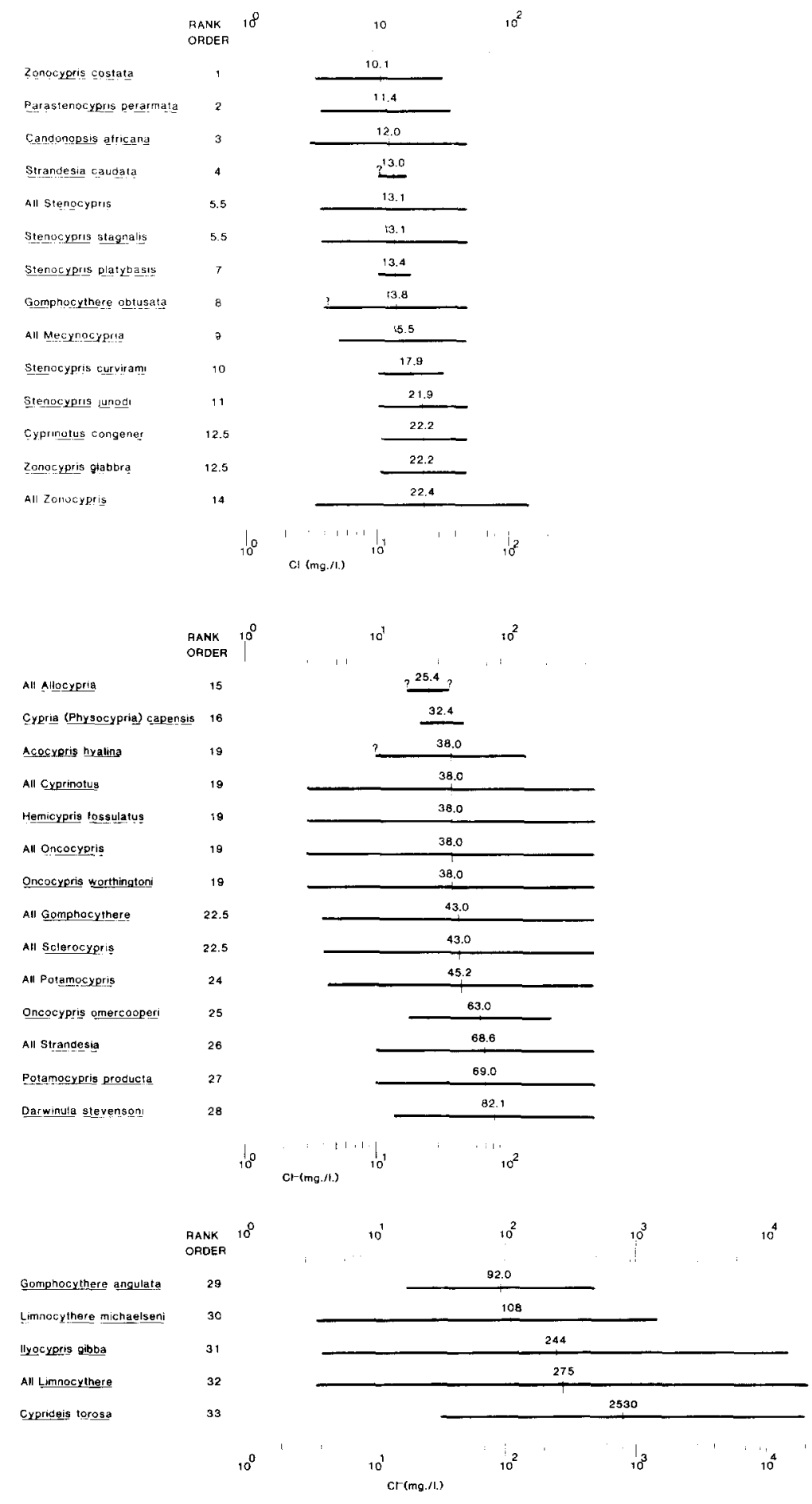

Fig.5. $\mathrm{Cl}^{-}$concentration ranges (expressed in $\mathrm{mg} / \mathrm{l}$ ) for selected African ostracode taxa, based on natural distributions. Rank order values are based on increasing logarithmic means of minimum and maximum concentration values. 


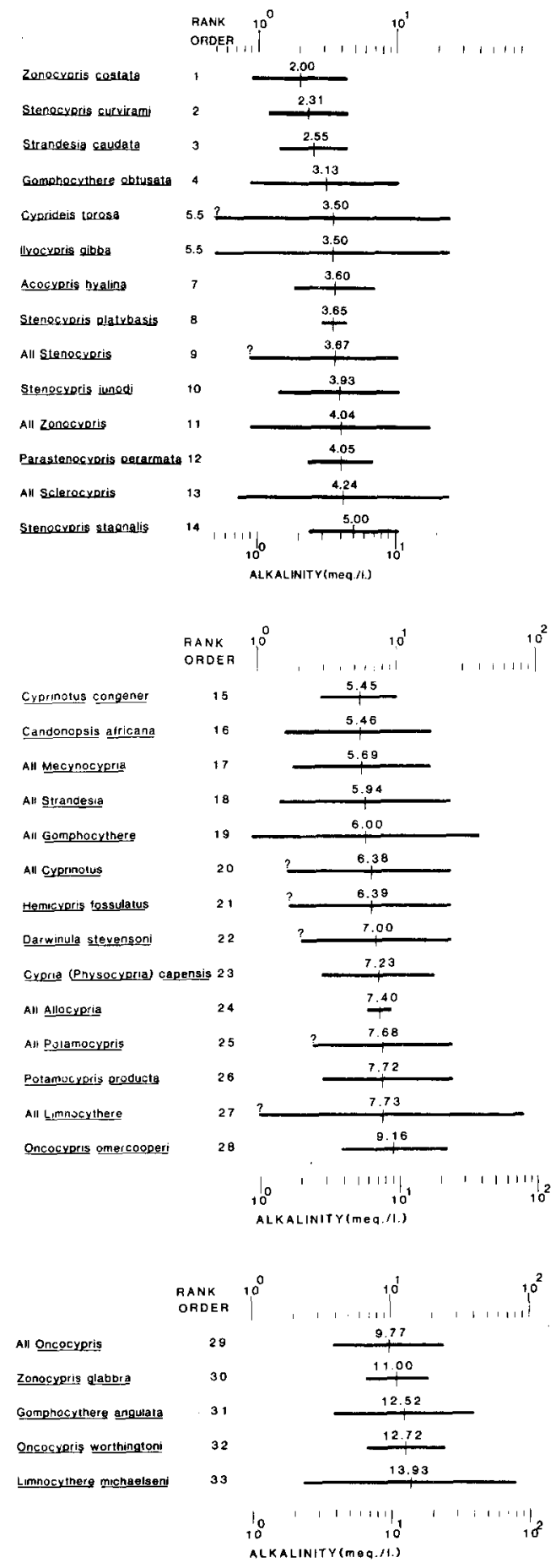

Fig.6. Alkalinity $\left(\mathrm{CO}_{3}^{2-}+\mathrm{HCO}_{3}^{-}\right)$concentration ranges (expressed in meq/l) for selected African ostracode taxa, based on natural distributions. Rank order values are based on increasing logarithmic means of minimum and maximum concentration occurrences. 
known distribution of each species or genus may be obtained from the senior author on request. For each Figure, the ostracode taxa are arranged in order of increasing logarithmic means (between maxima and minima) in their ranges for the chemical species in question. These means should not be interpreted as either the optimal or median portion of the ostracode's range. Rather, their importance lies in allowing a comparison of the ordering of species between chemical parameters. Using this information, it is possible to determine those parameters, if any, which can be isolated from the others as having unique effects on the types of taxa present as ionic concentration is increased, and those which are not empirically separable using natural distribution data alone.

All species and genera are assigned a rank number in order of increasing ionic concentration of their means, for each parameter (see Figs.2-6). A Spearman Rank Order Correlation was then performed for each pair of parameters. These are illustrated in matrix form in Fig. $7 . \mathrm{Na}^{+}, \mathrm{Cl}^{-}$and $K_{20}$ are all very highly and significantly correlated $(p<0.01)$, indicating that: (a) ostracode assemblages vary uniformly along concentration gradients for each of these three parameters; and (b) using distribution data alone, the effects of any one of these parameters cannot be factored out from the other two. Thus, for instance, a high $K_{20}$, low $\mathrm{Na}^{+}$ostracode fossil assemblage could not be detected from these data. In fact, such noncoordinate variation in these three water chemistry parameters does not presently exist in Eastern Africa.

Alkalinity is also positively correlated with these three parameters, but at a less significant level. The species primarily responsible for this lowered correlation (Cyprideis torosa and Ilyocypris gibba) are euryhaline-estuarine species, which are evidently tolerant of a wide range of alkalinities, from the relatively low $\mathrm{CO}_{3}^{2-}+\mathrm{HCO}_{3}^{-}$present in most estuaries, to the highly alkaline soda lakes.

$\mathrm{Ca}^{2+}$ ranges for African ostracodes are negatively and insignificantly related to the other four factors. Many nonalkaline, $\mathrm{Ca}^{2+}$-poor waters of Eastern

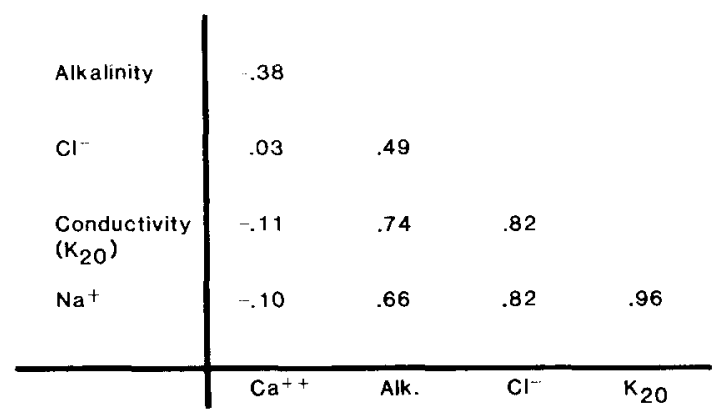

Fig.7. Rank order correlation coefficient matrix. This matrix illustrates the relationship between the five ionic parameters considered in this study with respect to their coordinate effects on ostracode assemblage variations. See text for full discussion. $K_{20}, \mathrm{Cl}^{-}$, alkalinity and $\mathrm{Na}^{+}$are all positively and significantly correlated with each other $(p<0.01)$, indicating that their individual effects on the ostracode assemblage cannot be factored out from natural distributions alone. 
Africa (for example, Lake Victoria) are similarly poor in other ionic constituents, while, as previously mentioned, more highly alkaline waters, like Lake Turkana, are also low in $\mathrm{Ca}^{2+}$, due to low saturation values. It would appear that few of these widespread species can live in very low $\mathrm{Ca}^{2+}$ waters (below $5 \mathrm{mg} / \mathrm{l})$. However, in a situation analogous to adaptation for high alkalinity in Lake Turkana, there are numerous endemic, low- $\mathrm{Ca}^{2+}$ species in Lake Victoria (Lindroth, 1953; A. C. Cohen, pers. obs.). Extracting Ca from water across such a tremendous concentration gradient is a highly energy-intensive activity for shelly invertebrates (Beadle, 1974). The upper "limits" of $\mathrm{Ca}^{2+}$ values illustrated for these ostracode taxa almost certainly are artifacts of the typically low $\mathrm{Ca}^{2+}$ concentrations of African inland waters. Again, wideranging values for $I$. gibba and $C$. torosa result from their dual presence in high $\mathrm{Ca}^{2+}$ estuarine environments and low $\mathrm{Ca}^{2+}$ sodic environments. Thus, the $\mathrm{Ca}^{2+}$ concentration does not appear to be the principal limiting factor in the distribution of these two species.

\section{Ostracode assemblages in relation to alkalinity}

Alkalinity is perhaps the chemical parameter most widely discussed in reference to African lacustrine faunal and floral distribution (Jenkin, 1936; Hustedt, 1949; Talling and Talling, 1965; McLachlan and McLachlan, 1969; Hecky and Kilham, 1973; Beadle, 1974). Four broad ranges of alkalinity values appear to correlate with some aspects of ostracode distribution. The absolute boundaries of these ranges are, of course, somewhat arbitrary, reflecting a combination of sampling bias and reality. The assemblage ranges (Fig.8) are named for the most distinctive or diagnostic member taxa.

Range I: less than 0.5(?)-5 meq/l (the Stenocypris Assemblage). Nearly all species of the cosmopolitan (both Paleotropical- Ethiopian and Neotropical in distribution) genus Stenocypris occur in the relatively fresh waters of this range. Preliminary evidence suggests that the closely related genera Chrissia and Parastenocypris may also be typical of this range. Particularly notable as indicators of this range are the common species $S$. platybasis and Zonocypris costata, the latter of which has already been described from the Eastern African fossil record (Carbonel and Peypouquet, 1979). The absence of ostracode assemblages representative of carbonate-bicarbonate-poor waters $(<0.5 \mathrm{meq} / \mathrm{l})$ merely reflects the fact that such lakes are relatively rare and undocumented in this region of Africa.

Range II: $5-15$ meq/l (the Mecynocypria ${ }^{1}$ Assemblage). Mecynocypria is an extremely useful indicator of this water chemistry range, occurring only rarely in Range I waters. Additionally, Allocypria and Physocypria (members of the same clade) occur in Range II waters, though Physocypria may be found in Range I waters more commonly than Mecynocypria. The genus

\footnotetext{
${ }^{1}$ This Assemblage was referred to as the Paracypria Assemblage in Cohen (1982). Paracypria is no longer considered a valid genus for these African species, Rome (1962) having placed it in either Allocypria or Mecynocypria (K. G. McKenzie, pers. commun., 1981).
} 


\begin{tabular}{|c|c|c|c|c|c|c|}
\hline RANGE * & NAME & $\mathrm{Na}^{+}$ & $\mathrm{Cl}^{-}$ & Alkalinity & $\mathrm{K}_{20}$ & $\begin{array}{l}\text { Comparison } \\
\text { with Talling } \\
\text { and Talling } \\
\text { classification }\end{array}$ \\
\hline 1 & $\begin{array}{l}\text { Stenocypris } \\
\text { Assemblage }\end{array}$ & $<75$ & $<20$ & $<5.0$ & $<500$ & $\begin{array}{l}\text { Class } 1 \\
(<600)\end{array}$ \\
\hline II & $\begin{array}{l}\text { Mecynocypria } \\
\text { Assemblage }\end{array}$ & $75-150$ & $20-50$ & \multicolumn{2}{|c|}{$5-15 \quad 500-1500$} & \multirow{2}{*}{$\begin{array}{c}\text { Class } 2 \\
(600-6000)\end{array}$} \\
\hline III & $\begin{array}{l}\text { Gomphocythere } \\
\text { Assemblage }\end{array}$ & $\begin{array}{l}150- \\
900\end{array}$ & $50-500$ & $15-30$ & $\begin{array}{l}1500- \\
4000\end{array}$ & \\
\hline IV & $\begin{array}{l}\text { Limnocythere } \\
\text { Assemblage }\end{array}$ & $>900$ & $>500$ & $>30(-80 ?)$ & $>4000$ & $\begin{array}{l}\text { Class } 3 \\
(>6000)\end{array}$ \\
\hline
\end{tabular}

Fig.8. Ostracode assemblage ranges. The range number is followed by the most distinctive or commonplace genus of that range. Only for Range II is the genus absolutely restricted to that range, however. See discussion in text. $\mathrm{Na}^{+}$and $\mathrm{Cl}^{-}$values are in $\mathrm{mg} / \mathrm{l}$ alkalinity $\left(\mathrm{CO}_{3}^{2-}+\mathrm{HCO}_{3}^{-}\right)$in meq/l and $K_{20}$ (conductivity) in $\mu \mathrm{mho} / \mathrm{cm}$. Talling and Talling's (1965) classification scheme (values are $K_{20}$ ) is included for comparison.

Allocypria today occurs only in lakes Tanganyika and Albert (and possibly Europe), but was apparently more widespread in Eastern Africa during the Late Pleistocene (fossils of Allocypria have been recovered from the Nakuru, Elmentaita, and Turkana basins). Its extreme stenotopy, however, for alkalinity (6-9 meq/l), as well as for other ionic parameters, suggests that it may be a very valuable paleochemical indicator. Additional genera, in particular Eucypris and Pseudocypris, are currently under study as potential Range I and II indicators.

Cypris, a very important Range I and II ostracode genus, has a worldwide distribution. Unfortunately, most African species of this genus seem to have very limited geographical ranges, with the possible exceptions of $C$. neumanni and C. latissima (Lindroth, 1953). The identification of particular species of this genus, or often the genus itself, from fossils is usually difficult, thus reducing the utility of an otherwise potentially useful group for paleochemical analysis.

Range III: 15-30 meq/l (the Gomphocy there Assemblage). This range of alkalinities is occupied largely by eurytopic species, which also live in less alkaline waters. No ostracode genus from Africa (including Gomphocythere) is known to occur exclusively in waters more alkaline than $7 \mathrm{meq} / \mathrm{l}$. Endemic species of Gomphocy there, Cyprinotus, Potamocypris, Hemicypris, Cypridopsis, and Schlerocypris occur in Ethiopian lakes of this type, as well as in Lake Turkana (alkalinity: $19 \mathrm{meq} / \mathrm{l}$ ). Additionally, these same genera, as well as Oncocypris, Ilyocypris and Cyprideis (and a number of less important genera), are all represented by cosmopolitan species whose alkalinity tolerances extend into this range. 
Range IV: $>30 \mathrm{meq} / \mathrm{l}$ (the Limnocythere Assemblage). Few species of ostracodes are known from highly alkaline waters for reasons already discussed, and none to our knowledge are absolutely diagnostic of them. Two species, Limnocythere michaelseni and Gomphocythere angulata, are the only ones currently known from such African waters, the latter only barely extending into the range.

The species Cyprideis torosa and Ilyocypris gibba, both of worldwide as well as African distribution, can tolerate high (Range IV equivalent) salinities, but have not been reported from lakes more alkaline than 25 meq/l. This suggests that these species are truly estuarine adapted, as opposed to being generalists for all types of ionically concentrated waters.

The upper limit of alkalinity tolerance for ostracodes as a group is unknown. An occurrence of Limnocy there michaelseni in Lake Abiata, Ethiopia, when the lake had an alkalinity of $80 \mathrm{meq} / \mathrm{l}$ is well documented (OmerCooper, 1930; Lowndes, 1932). A characteristic feature of highly alkaline lakes, however, is their enormous variability in water chemistry. Such lakes tend to be shallow pans, subject to seasonal or more infrequent fluctuations of water level and chemistry due to local weather variations (Livingstone and Melack, 1979).

A study by Wiederholm (1980) of Lake Lenore (Wash., U.S.A.), an alkaline lake being progressively diluted by inflowing irrigation projects, showed that ostracodes colonized the lake when the alkalinity had dropped to 15-20 meq/l. McLachlan and McLachlan (1969) reported no ostracodes in a study of Lake Chilwa (Malawi) during a drying phase in 1967 when conductivities rose over $10,000 \mu$ mho. From correlations developed by Talling and Talling (1965) between conductivity and alkalinity in these types of lakes, it is possible to estimate the alkalinity during this drying phase at over $100 \mathrm{meq} / \mathrm{l}$. McKenzie (1970), in a biogeographical review of non-marine ostracodes from the Southern Hemisphere, noted that a number of Australian ostracodes have been recorded in waters with total ionic concentrations in excess of 30 p.p.t., the genus Diacypris being recorded in waters as concentrated as 131.4 p.p.t. (Bayly and Williams, 1966; McKenzie, 1970, after Bayly). It is clear from the research of Rawson and Moore (1944), Hammer et al. (1975) and Wiederholm (1980) that ionic concentration tolerances are quite variable for lacustrine invertebrates, dependant principally on the ionic species present, with considerably higher tolerances being noted for sodium chloride and sodium sulphatochloride waters than for sodium carbonate-bicarbonate waters (the principal type of Eastern Africa).

No long-term studies of ostracode populations in the alkaline lakes of Africa have yet been attempted, so we can only speculate about their occurrences in waters more alkaline than $80 \mathrm{meq} / \mathrm{l}$. In two cases, however, highly alkaline lakes which do not suffer regular drying are known to be devoid of ostracodes. Both of these lakes, Sonachi Crater Lake (near Lake Naivasha) and Central Island Crater Lake A (at Lake Turkana) are believed, from altimetric studies for this report, to be in subterranean communication with their larger, neighboring bodies of water. Local volcanic runoff in both cases 
serves to maintain alkalinities higher than the parent lake, which nevertheless keeps the water volumes and levels in these craters much more constant than would otherwise be possible. Since both of these crater lakes lie in the range of 50-100 meq/l alkalinity, and neither appears to have any unusual chemical characteristics for lakes of this alkalinity, the occurrence of ostracodes at $80 \mathrm{meq} / \mathrm{l}$ would appear to be near the natural limit.

The identification of ostracode assemblages as being diagnostic of Range III or IV paleochemistries obviously relies on the negative evidence of absence of lower-alkalinity-range ostracode taxa. Since no widespread species can be considered diagnostic of these ranges, this is an unavoidable limitation on the methodology presented here. Field studies, however, suggest that this may be a relatively minor problem. In the course of over 300 dredge hauls from Kenyan lakes for this report, and numerous accounts of other workers (e.g., Klie, 1933; Lowndes, 1932; Lindroth, 1953; Rome, 1962), no Range III or IV assemblages - that is to say assemblages which were totally devoid of fresher-water species - were ever recovered from lakes whose water chemistries did not correspond with those ranges respectively. For example, while Limnocythere michaelseni, a Range IV assemblage species, has been reported from Lake Tanganyika (a Range II lake) and Lake Turkana (a Range III lake), no monospecific assemblages of $L$. michaelseni have ever been found in either Tanganyika or Turkana. When found in either of these lakes, it always seems to occur with fresher-water species as well. Therefore, paleoecological inferences based upon negative evidence (in this case the absence of key taxa), although always less desirable than those based upon a taxon's presence, may be justified, as in this case where other supporting evidence is simply unavailable, and where sufficient empirical evidence exists to support its application.

\section{PALEOECOLOGICAL APPLICATIONS}

Of the 33 taxa discussed here, 21 have been found as fossils in Miocene-Holocene Eastern African lake sediments. Since the study of fossil fresh-water ostracodes from Eastern Africa is only in its infancy, it seems likely that even more of the listed taxa will eventually be recovered as fossils. Fossil occurrences thus far documented are listed separately (available from the senior author on request).

Ostracode occurrence data from several cores taken in Lakes Nakuru, Elmentaita and Naivasha of the Kenyan (Gregory) Rift Valley were gathered by two of the authors (R. D. and J. R.). The original data appeared in an unpublished manuscript (Dussinger, 1973). One of these sets of core data (from Lake Nakuru) was chosen to illustrate the application of the technique discussed in this paper to lacustrine paleochemical analyses. This core has also been analyzed by Richardson (1979) for its diatom content (again in relation to water chemistry), which will serve as an independent check on the validity of our interpretation. 


\section{The Lake Nakuru core}

Lake Nakuru, a small alkaline lake, lies in the Gregory Rift Valley, approximately $120 \mathrm{~km}$ northeast of Nairobi. At the present time, it occupies a closed basin at approximately $1750 \mathrm{~m}$ above mean sea level. Its modern water chemistry (Table I) is quite variable due to its shallow and greatly fluctuating depth $\left(z_{\max }=2.5 \mathrm{~m}\right)$.

Richardson extracted a 19.5-m core from Lake Nakuru during his 1969-70 field season. The core was sampled every $20 \mathrm{~cm}$ for its ostracode content. The ostracode stratigraphy is illustrated in Fig.9A. A detailed account of the analysis of this core will appear shortly (Richardson, in prep.).

Many of the genera (and some of the species) described by Dussinger from the Nakuru core are among those discussed in the first part of this paper, and are therefore of use in this application. For example, the presence of Mecynocypria (cf. $M$. reniformis) at several levels of the core suggests that the alkalinity at those levels was between 5 and $15 \mathrm{meq} / \mathrm{l}$. For other levels, the overlapping ranges of two coexisting taxa yield the probable water chemistry at that level. For example, at $370 \mathrm{~cm}$ the co-occurrence of Limnocythere michaelseni $\left(\mathrm{Na}^{+}\right.$range $\left.20-3200 \mathrm{mg} / \mathrm{l}\right)$ with Gomphocythere obtusata $(10-$ $115 \mathrm{mg} / \mathrm{l}$ ) suggests a $\mathrm{Na}^{+}$range of $20-115 \mathrm{mg} / \mathrm{l}$, for Lake Nakuru's water at the time of deposition (and for the part of the lake where the core was taken). More alkaline conditions (Range IV) must have been present in Lake Nakuru at the $850-\mathrm{cm}$ level time, when a monospecific Limnocythere assemblage formed. The absence of ostracodes for $180 \mathrm{~cm}$ above and $60 \mathrm{~cm}$ below this point in the core may suggest that alkalinity concentrations during these time intervals exceeded $80 \mathrm{meq} / \mathrm{l}$.

Fig.9B compares composite interpretations of the Nakuru core paleochemistries based upon both ostracode and diatom typology. The agreement of the two techniques appears to be quite good, and it must be emphasized that the two techniques were derived entirely independently of each other. This should be encouraging news to diatomists studying lacustrine paleochemistries in the absence of corroborative evidence. Major variances in interpretation between the ostracode and diatom methodologies occur at two intervals: $1175-950 \mathrm{~cm}$ and $360-310 \mathrm{~cm}$. At the moment, no satisfactory explanation can be offered to explain these discrepancies, although they are under further study in an effort to resolve this problem. For $80 \%$ of that portion of the core which contains both ostracodes and diatoms, the trends of increasing and decreasing ionic concentrations follow each other. Fluctuating alkaline to moderately fresh water occurred between $800-300 \mathrm{~cm}$ time at the core site, with fresh-water conditions following from $300-30 \mathrm{~cm}$, and finally a return to alkaline conditions near the top of the core.

$\mathrm{Up}$ to this point, the fossil ostracode occurrences have been evaluated entirely on presence-absence data. Whereas it is tempting to consider valve ratios as being of importance in evaluating probable paleochemistries, this approach must be considered carefully (and indeed was rejected for this preliminary study) for two compelling reasons. 


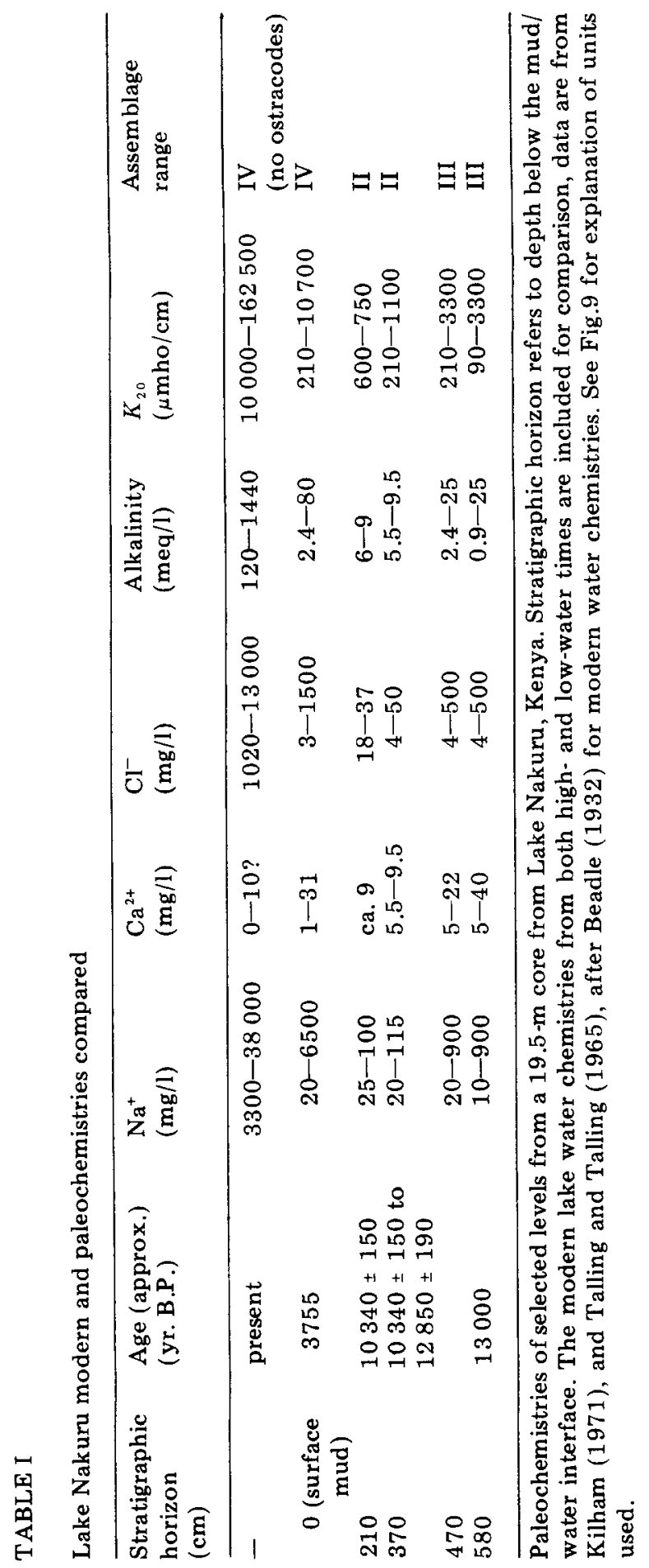




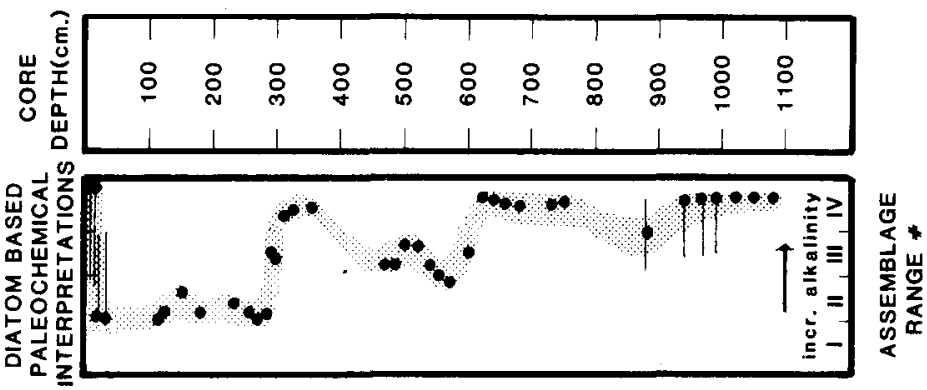

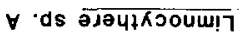

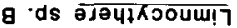

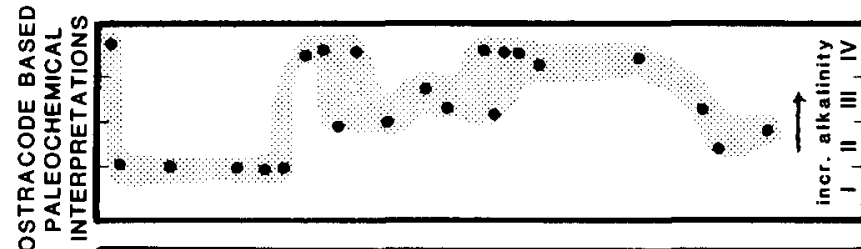

。

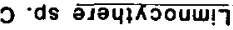

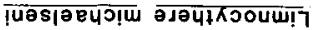

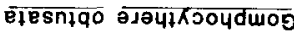

$\forall \cdot d s \overline{\text { s!sdop!dono }}$

g d ds s!sdop!idKo

$\partial \cdot 9$ s!sdop!jdK5

$a \cdot d s$ s!sdop!dako

हाएлеगषว

$\cdot d s \overline{s ! d} \overline{j k J 0200}$

-ds हागdKo

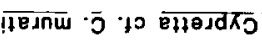

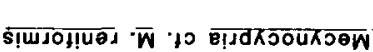

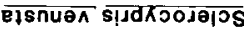
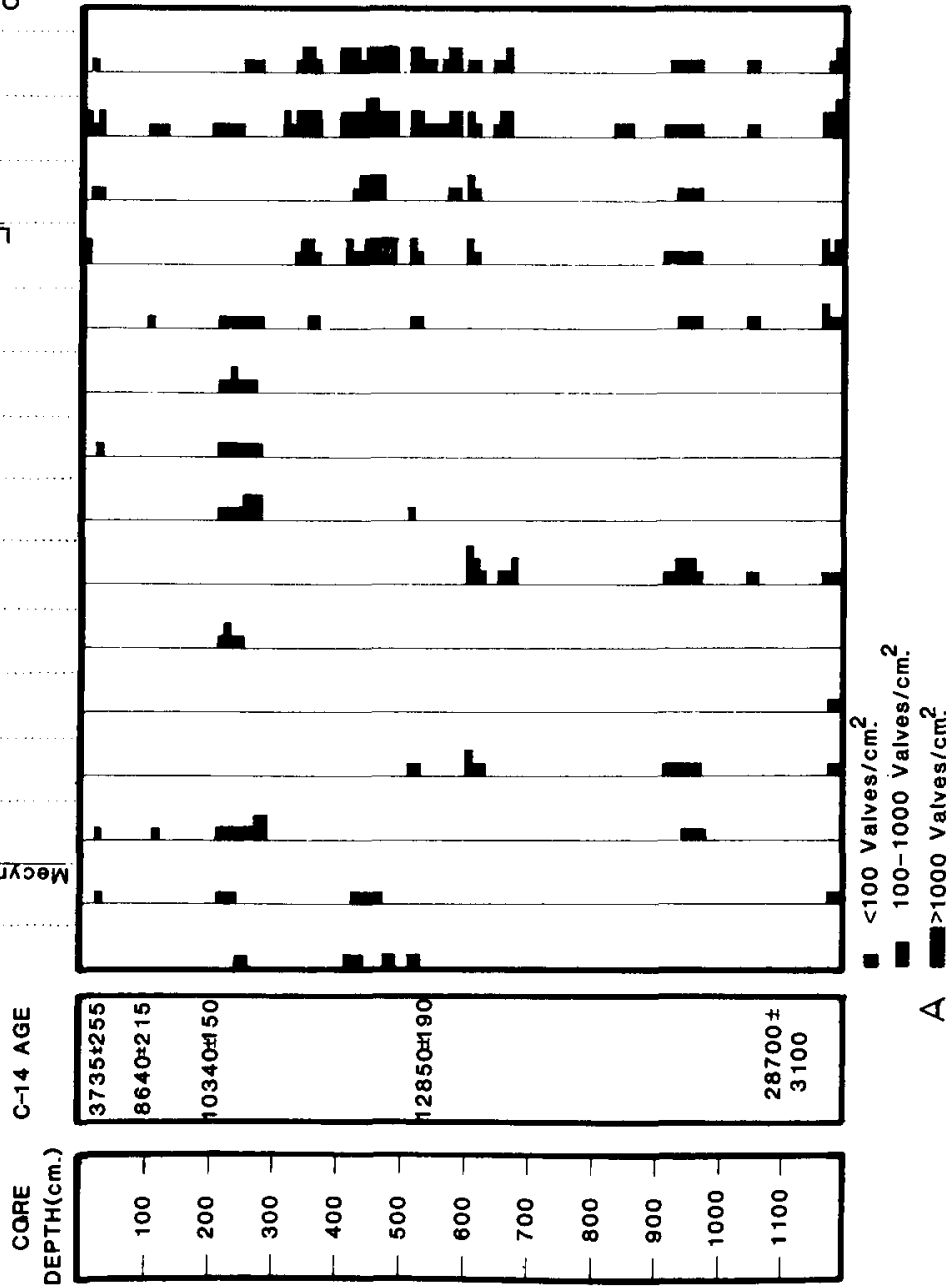
First, the initial distribution ratios of ostracodes during life are controlled by a variety of environmental and biotic factors aside from water chemistry. Temperature variability is probably insignificant in lowland (under $2000 \mathrm{~m}$ ) equatorial Africa, but local, microenvironmental variations (for example, algal $v$ s macrophytic substrates) will often lead to several ostracode associations within a given lake. This has been confirmed in studies of the ostracode fauna of Lake Turkana, where two distinctive ostracode associations may be recognized (Cohen, 1982) associated with water depth variations, for reasons which are not yet entirely clear. Thus, an abundance of a given species at the expense of another may not reflect a more advantageous water chemistry for the first, but rather could reflect an advantage along any environmental gradient of significance to ostracodes.

The second problem, potentially even more intractable than the first, concerns the selective post-mortem transport and preservation of ostracode valves. Ostracode valves have been observed in the course of this study to float quite readily after death and be transported, often in large numbers, out of their life habitats. This again makes the counting of valve ratios of dubious value, until such time as these taphonomic problems can be sorted out. Surprisingly however, this admixture of valves actually works to the advantage of a paleochemical analysis by assuring that a greater percentage of the lake's ostracode fauna (by species) will be represented in a single sample. This in turn allows for a greater probability that a narrow range of paleochemical interpretations may be inferred. Returning to the Lake Turkana example, a typical sublittoral, silty bottom sample contains $3-5$ species of live ostracodes, whereas the sediment from the same locality will often contain up to 8-9 species, represented by valves only, an admixture from deeper and shallower water.

\section{CONCLUSIONS}

Typologies have proved useful in characterizing lake water chemistries by their inhabitant floras (Richardson, 1968) and faunas (LaBarbera and Kilham, 1974). When the group of organisms subjected to a typological study leaves behind a significant, taxonomically identifiable fossil record in lacustrine deposits, the typology can be inverted to yield paleochemical data about the ancient lakes in question. Eastern and Southern African lakes provide an ideal setting for such studies for two reasons: (1) a very wide range of water chemistries is represented there; and (2) many of these lakes have geologic records extending well back into the Pleistocene or earlier.

Fig.9. Ostracode stratigraphy and paleochemical interpretations from Lake Nakuru, for the upper $12 \mathrm{~m}$ of a 19.5 -m core. A. Ostracode stratigraphy after Dussinger (1973, p. 24b) showing valve abundances of all taxa present per $\mathrm{cm}^{3}$ wet sediment. B. Paleochemical interpretations of the Lake Nakuru core based upon ostracode fauna and diatom flora. Diatom data are from Dussinger (1973, p. 24c) and Richardson (1979). The independent interpretations of paleochemistry based on ostracodes and diatoms show good agreement for all intervals except $1175-950 \mathrm{~cm}$ and $360-310 \mathrm{~cm}$. 
Ostracodes are well suited for this type of study (Delorme, 1969). Thirty three taxa (genera and species) were investigated and their water chemistry ranges plotted for five chemical parameters $\left(\mathrm{Na}^{+}, \mathrm{Ca}^{2+}, \mathrm{Cl}^{-}, \mathrm{CO}_{3}^{2-}+\mathrm{HCO}_{3}^{-}\right.$ alkalinity, and total conductivity $K_{20}$ ). Ostracodes, being highly calcified crustaceans, are excluded from highly alkaline waters with low (less than $1 \mathrm{mg} \mathrm{l)} \mathrm{Ca}^{++}$solubilities.

The ordering of the ostracode tolerance ranges for four of the parameters $\left(\mathrm{Na}^{+}, \mathrm{CO}_{3}^{2-}+\mathrm{HCO}_{3}^{-}\right.$alkalinity, $\mathrm{Cl}^{-}$and $\left.K_{20}\right)$ are highly coordinated, suggesting that the effects of these parameters cannot be individually factored out in distribution studies of ostracodes in natural waters from this region.

Ostracode assemblages typical of particular levels of ionic concentration can be characterized by four broad assemblage ranges. Range I (the Stenocypris assemblage) and IV (the Limnocythere assemblage) roughly correspond to Talling and Talling's (1965) Class I $\left(K_{20}<600 \mu \mathrm{mho}\right)$ and lower Class III $\left(K_{20}>6000 \mu \mathrm{mho}\right)$ respectively, whereas Ranges II (the Mecynocypria assemblage) and III (the Gomphocythere assemblage) would in toto be approximately equivalent to their Class II waters $\left(K_{20}=600-6000 \mu \mathrm{mho}\right)$.

An example of the application of ostracode typology to fossils in a 19.5-m core from Lake Nakuru illustrates the technique. Nakuru, which today is a highly concentrated, alkaline brine, was much more dilute in the recent geological past. Fluctuations between Range II and IV ostracode faunas can be documented in this core through much of the latest Pleistocene and Early Holocene. These results are corroborated by studies of diatom typology (Richardson, in prep.) of the same core. The broad similarity of results between paleochemistries determined using these two entirely independent techniques is very encouraging.

As a final note of caution, we have considered (and rejected for this first study) one easily suggested refinement of our technique. Tabulating ratios of species present in a fossil assemblage rather than merely their presence or absence (as we have done here) is a normal tool of the trade among paleoecologists. Experience with living populations of ostracodes in Lake Turkana has led us to believe that such ratios may be misleading when taphonomic and ecologic complications (derived from significant post-mortem sorting and microhabitat variations) arise.

This technique is still in its infancy, and many refinements are certain to be made to it, both in an effort to "fine tune" it and make it more comprehensive. Nonetheless, it has already proven its worth as a valuable tool in the interpretation of the complex yet fascinating history of the Eastern African Rift Valley lake's.

\section{ACKNOWLEDGEMENTS}

We would like to thank a number of people who have made this work possible. Messrs. P. Kongere, P. Ojuok, and B. Ogilio of the Kenya Department of Fisheries and Wildlife were very supportive of our field research, as 
was Mr. E. K. Ruchiami of the Office of the President, and the staff of the Lake Turkana Fisheries Station at Kaliokwell-Ferguson's Gulf, Kenya. To Cohen's assistants Karen Higgins and Nancy Dickinson we owe an enormous debt for their time spent in the field collecting data. Drs. Leo Laporte and A. Kay Behrensmeyer have generously supported this work on NSF Grant \#EAR-77-2349 (University of California at Santa Cruz), and with many hours of discussion. Additional funding was provided by grants from the University of California at Davis and Amoco Inc. The manuscript was read by D. Livingstone, R. Bate, F. Swain, D. Delorme, K. G. McKenzie, R. Cowen and L. Laporte. For all of their comments and criticisms we are grateful.

\section{REFERENCES}

Bayly, I. A. E. and Williams, W. D., 1966. Chemical and biological studies on some saline lakes of Southeast Australia. Aust. J. Mar. Freshwater Res., 17: 177-228.

Beadle, L. C., 1932. Scientific results of the Cambridge Expedition to the East African Lakes, 1930-31. 4. The waters of some E. African Lakes in relation to their fauna and flora. J. Linn. Soc. (Zool.), 38: 157-211.

Beadle, L. C., 1943. An ecological survey of some inland waters of Algeria. J. Linn. Soc. (Zool.), 41: 218-242.

Beadle, L. C., 1974. The Inland Waters of Tropical Africa. Longman, London, New York, NY, $365 \mathrm{pp}$.

Carbonel, P. and Peypouquet, J., 1979. Les Ostracodes des Séries du Bassin de l'Omo. Bull. Inst. Géol. Aquitaine, Bordeaux, No. 25: 167-199.

Cerling, T. E., 1977. Paleochemistry of Plio-Pleistocene Lake Turkana and Diagenesis of Its Sediments. Dissertation, University of California at Davis, CA, 180 pp.

Cohen, A. C., 1982. Ecological and Paleoecological Aspects of the Rift Valley Lakes of East Africa. Dissertation, University of California at Berkeley, CA, $314 \mathrm{pp}$.

Damas, H., 1937. Recherches hydrobiologiques dans les lacs Kivu, Edouard et Ndagala (Congo Belge). Verh. Int. Ver. Limnol, 8: 51-68.

Damas, H., 1954. Etude limnologique de quelques lacs ruandais. III. Le plancton. Mem. Acad. Sci. Colon. Belge, Classe Sci, N.S., 3: 1-66.

Damas, H., 1964. Le Plancton de quelques lacs d'Afrique Centrale. Verh. Int. Ver. Limnol., 15: $128-138$.

De Kimpe, P., 1960. Observations hydrobiologiques au Laupula-Moero. Hydrobiologie et pêche en eaux douces. In: Colloque sur les problèmes des Grand Lacs, Lusaka, 1960. CCTA/CSA LACS, 39: $17 \mathrm{pp}$.

Delorme, L. D., 1969. Ostracodes as Quaternary paleoecological indicators. Can. J. Earth Sci., 6: 1471-1476.

Delorme, L. D., 1971a. Paleoecological determinations using Pleistocene freshwater ostracodes. In: H. C. Oertli (Editor), Paléoécologie d'Ostracodes. Bull. Centre Rech. SNPA, Pau, pp. 341-347.

Delorme, L. D., 1971b. Paleoecology of Holocene sediments from Manitoba using freshwater ostracodes. Geol. Assoc. Can. Symp., Spec. Pap., No. 9, pp. 301-304.

Delorme, L. D., Zoltai, S. C. and Kalas, L. L., 1977. Fresh water shelled invertebrate indicators of paleoclimate in Northwestern Canada during the late glacial. Can. J. Earth Sci., $14: 2029-2046$.

Dubois, J. T., 1955. Etude hydrobiologique d'un lac africain: Le Lungwe. Etude physique et chémique. Bull. Centre Belge Etude Doc. Eaux, 53: 79-82.

Dussinger, R., 1973. The Environmental Reconstruction of African Rift Lakes Using Ostracodes as Paleoecological Indicators. Thesis, Franklin and Marshall College, Lancaster, PA, 37 pp. (unpublished). 
Eugster, H. P., 1980. Geochemistry of evaporitic lacustrine deposits. Annu. Rev. Earth Planet. Sci., 8: 35-83.

Eugster, H. P. and Jones, B. F., 1979. Behavior of major solutes during closed basin brine evolution. Am. J. Sci., 279: 609-631.

Fish, G. R., 1952. Appendix A. Annual Report for 1951. E. Afr. Fish Res. Org. Jinja, Uganda. E. Afr. High Comm., 49 pp.

Fish, G. R., 1953. Appendix A. Chemical Analyses. Annual Report for 1952. E. Afr. Fish. Res. Org., Jinja, Uganda. E. Afr. High Comm., 42 pp.

Fish, G. R., 1954. Appendix A1-A6. Annual Report for 1953. E. Afr. Fish. Res. Org., Jinja, Uganda. E. Afr. High Comm., 44 pp.

Hammer, U. T., Haynes, R. C., Heselfine, J. M. and Swanson, S. M., 1975. The saline lakes of Saskatchewan. Verh. Int. Ver. Limnol., $19: 589-598$.

Hardie, L. A. and Eugster, H. P., 1970. The evolution of closed basin brines. Mineral. Soc. Am. Spec. Publ., 3: 273-290.

Harding, D., 1963. Studies of Lake Nyasa and associated rivers. In: Jackson et al. (Editor), Report on the Survey of Northern Lake Nyasa. Joint Fish. Res. Org. 1954-55. Government Printing Office, Zomba, Malawi, $171 \mathrm{pp.}$

Hecky, R. E. and Kilham, P., 1973. Diatoms in alkaline saline lakes; Ecology and geochemical implications. Limnol. Oceanogr., 18: 53-71.

Hustedt, F., 1949. Süsswasser-Diatomeen. Exploration du Parc National Albert. Mission H. Damas (1935-36), No. 8. Inst. Parcs Natl. du Congo Belge, Brussels, 199 pp.

Jenkin, P. M., 1936. Report on the Percy Slade Expedition to some Rift Valley Lakes in Kenya in 1929. VII. Summary of the ecological results with special reference to the alkaline lakes. Annu. Mag. Nat. Hist., Ser. 101, 18: 133-181.

Kilham, P., 1971. Biogeochemistry of African Lakes and Rivers. Dissertation, Duke University, Durham, NC, $191 \mathrm{pp}$.

Klie, W., 1933. Report on the Percy Slade Expedition to some Rift Valley Lakes in Kenya in 1929. Die Ostracoden der Rift-Tal-Seen in Kenia. Int. Rev. Gesamten Hydrobiol. Hydrogr., 29: 1-14.

LaBarbera, M. C. and Kilham, P., 1974. The chemical ecology of copepod distribution in the lakes of East and Central Africa. Limnol. Oceanogr., 9: 459-465.

Lindroth, S., 1953. Taxonomic and zoogeographic studies of the ostracode fauna in the inland waters of East Africa. Zool. Bidr. Upps. Univ., 30: 43-156.

Livingstone, D., 1963. Chemical composition of rivers and lakes. U.S. Geol. Surv. Prof. Pap., 400-G: 64 pp.

Livingstone, D. and Melack, J., 1979. The Lakes of Subsaharan Africa. SIL-UNEP Workshop on African Limnology, $46 \mathrm{pp}$.

Loffredo, S. and Maldura, C. M., 1941. Risultati generali delle richerche di chimica limnologica sulle acque dei laghi dell'Africa orientale italiana esplorati dalla Missione ittiologica. In: A. Piccioli (Editor), Esplorazione dei laghi della Fossa Galla. Coll. Sci. Documen. Africa Ital., III, 1: 181-200.

Lowndes, A. G., 1932. Report on the ostracoda. Mr. Omer-Cooper's investigation of the Abyssinian fresh waters. Proc. Zool. Soc. Lond., Part 3: 667-708.

McKenzie, K. G., 1970. Paleozoogeography of freshwater ostracoda. In: H. J. Oertli (Editor), Paléoécologie d'Ostracodes. Bull. Centre Rech. SNPA, Pau, pp. 207-237.

McLachlan, A. J, and McLachlan, S. M., 1969. The bottom fauna and sediments in a drying phase of a saline African lake (Lake Chilwa, Malawi). Hydrobiologia, 34: 401-413.

Omer-Cooper, J., 1930. Dr. Hugh Scott's Expedition to Abyssinia. A preliminary investigation of the freshwater fauna of Abyssinia. Proc. Zool. Soc. Lond., Parts 1-2: 195207.

Peypouquet, J. and Carbonel, P., 1980. Les ostracodes indicateurs des paléoenvironnements lacustres des rifts de l'Afrique orientale au Plio-Pléistocène. C.R. Acad. Sci. Paris, 290: 563-566.

Phillips, T., 1930. Crocodiles in Africa. London Times, 11 April, 1930, p. 12. 
Rawson, D. S. and Moore, J. E., 1944. The saline lakes of Saskatchewan. Can. J. Res., 22: $141-201$.

Ricardo, C. K., 1939. Report on the Fish and Fisheries of Lake Rukwa in Tanganyika Territory and the Bangweulu region in Northern Rhodesia. Crown Agents for the Colonies, London, $78 \mathrm{pp}$.

Ricardo-Bertram, C. K., Borley, H. J. and Trewavas, E., 1942. Report on the Fish and Fisheries of Lake Nyasa. Crown Agents for the Colonies, London, $181 \mathrm{pp}$.

Richardson, J., 1968. Diatoms and lake typology in East and Central Africa. Int. Rev. Gesamten Hydrobiol., 59: 299-338.

Richardson, J., 1979. Paleolimnology of Lake Nakuru, Kenya (abstract). SIL -..U.N. Environ. Progr. Workshop on African Limnology, Abstr. of Poster Papers, p. 41.

Rome, D. R., 1962s Exploration hydrobiologique du Lac Tanganyika (1946-1947): Ostracodes. Inst. R. Sci. Nat. Belg., 3(8): 305 pp.

Talling, J. F., 1957. The longitudinal succession of water characteristics in the White Nile. Hydrobiologia, 11: 73-89.

Talling, J. F., 1963. Origin of stratification in an African Rift Lake. Limnol. Oceanogr., $8: 68-78$.

Talling, J. F. and Talling, I. B., 1965. The chemical composition of African lake waters. Int. Rev. Gesamten Hydrobiol., 50: 421-463.

Van der Ben, D., 1959. La végétation des rives des lacs Kivu, Edouard et Albert. Exploration Hydrobiologique des lacs Kivu, Edouard et Albert (1952-54), 3. Inst. R. Sci. Nat. Belg., 4(1): $191 \mathrm{pp}$.

Van Meel, L., 1953. Contribution à l'étude du lac Upemba. A. Le milieu physicochimique. Exploration du Parc National de l'Upemba, 9. Inst. Parcs Natl. Congo Belge, 190 pp.

Van Meel, L., 1954. Le phytoplancton. Exploration hydrobiologique de lac Tanganyika (1946-47) 4. Inst. R. Sci. Nat. Belg., 681 pp.

Verbeke, J., 1957. Recherches écologiques sur la faune des grands lacs de l'Est do Congo Belge. Exploration hydrobiologique des lacs Kivu, Edouard et Albert (1952-54) 3. Inst. R. Sci. Nat. Belg., 177 pp.

Visser, S. A., 1974. Composition of waters of lakes and rivers in East and West Africa. Afr. J. Trop. Hydrobiol. Fish., 3: 43-60.

Wayland, E. J., 1925. Petroleum in Uganda. Geol. Surv. Uganda Mem., No. 1. Crown Agents for the Colonies, London.

Wiederholm, T., 1980. Effects of dilution on the benthos of an alkaline lake. Hydrobiologia, 68: 199-208.

Worthington, E. G., 1929. The life of Lake Albert and Lake Kioga. Geogr. J., 74: 109132.

Worthington, E. B., 1930. Observations on the temperature, hydrogen ion concentrations and other physical conditions of the Victoria and Albert Nyanzas. Int. Rev. Gesamten Hydrobiol., $24: 328-357$.

Worthington, E. B., 1932. A Report on the Fisheries of Uganda Investigated by the Cambridge Expedition to the East African Lakes 1932-1933. Crown Agents for the Colonies, London, 88 pp. 